\title{
Mulemba
}

Revista Angolana de Ciências Sociais

\section{As implicações da identidade nacional na projecção externa de Angola}

The implications of national identity in the external projection of Angola

\section{Alberto Colino Cafussa}

\section{(2) OpenEdition}

Journals

\section{Edição electrónica}

URL: http://journals.openedition.org/mulemba/358

DOI: $10.4000 /$ mulemba.358

ISSN: 2520-0305

\section{Editora}

Edições Pedago

\section{Edição impressa}

Data de publição: 1 maio 2015

Paginação: 55-99

ISSN: 2182-6471

\section{Refêrencia eletrónica}

Alberto Colino Cafussa, «As implicações da identidade nacional na projecção externa de Angola», Mulemba [Online], 5 (9) | 2015, posto online no dia 28 novembro 2016, consultado o 26 janeiro 2021 URL: http://journals.openedition.org/mulemba/358 ; DOI: https://doi.org/10.4000/mulemba.358

Este documento foi criado de forma automática no dia 26 janeiro 2021.

Tous droits réservés 


\title{
As implicações da identidade nacional na projecção externa de Angola
}

The implications of national identity in the external projection of Angola

\author{
Alberto Colino Cafussa
}

\section{NOTA DO EDITOR}

Recepção do manuscrito: 10/07/2014

Conclusão da revisão: 20/04/2015

Aceite para publicação: 30/04/2015

\section{NOTA DO AUTOR}

Trabalho de avaliação da disciplina de "Conceito estratégico nacional», elaborado no âmbito do Doutoramento em Ciências Sociais, na especialidade de Estudos Estratégicos, no Instituto Superior de Ciências Sociais e Políticas (ISCSP) da Universidade de Lisboa, sob a orientação dos Professores Heitor Romano e Fátima Amante.

\section{Nota introdutória}

Os elementos ontológicos constituem a base de qualquer estratégia de um Estado, uma vez que todas as conquistas só serão possíveis se houver uma base de apoio consistente, cujos membros estejam dispostos a sacrificar as suas vidas para uma aspiração supostamente comum. É o que Ray Clin chama vontade nacional, definido como o grau da resolução que pode ser mobilizado entre os cidadãos nacionais para suportar as decisões governamentais em defesa e da política externa (ALMEIDA 2012: 336). Cabral 
Couto (1988) enquadra esses elementos (identidade nacional, patriotismo e coesão nacional) nas forças morais enquanto recursos fundamentais no potencial estratégico de um Estado.

Silva Ribeiro (2010) remete os elementos identitários para a tradição histórica (o que se pensa), da qual vai resultar uma filosofia política (o que se quer). Serão, pois, estes dois recursos que vão orientar a escolha, entre a multiplicidade dos objectivos políticos possíveis daqueles que irão ser prosseguidos em permanência pelo Estado, à luz dos fins últimos: os objectivos permanentes.

3 Nenhum Estado pode prosperar se não houver uma história, uma identidade e um fim comum para os seus cidadãos - uma temática bastante difícil em estados africanos, onde a diversidade étnica torna a construção da identidade nacional um exercício inglório ou mesmo infrutífero.

4 Em Angola, o debate sobre a existência ou não de uma Nação opõe políticos a estudiosos, por estes últimos acharem que os primeiros transformam uma aspiração em realidade. Este texto, não sendo uma resposta cabal a esta problemática, analisa as implicações da identidade nacional, como elemento ontológico de uma estratégia, na prossecução dos interesses estratégicos de Angola. Com efeito, o autor analisa o discurso político-jurídico do Estado, ao mesmo tempo que apresenta vários factos históricos que permitiram a conquista de uma consciência patriótica e a procura crescente de uma identidade nacional levada a cabo pelas instituições do Estado.

\section{A identidade nacional como valor em construção}

5 A identidade nacional é uma construção tão complexa como o são os conceitos de Estado e de nação que, para serem minimamente compreendidos, exigem uma análise exaustiva de vários vectores. Como sublinha Anthony Smith (1997), uma identidade nacional é fundamentalmente multidimensional que não pode ser reduzida a um simples elemento, nem mesmo por facções particulares de nacionalistas e muito menos pode ser induzida numa população através de meios artificiais. Com efeito, antes de qualquer abordagem sobre a identidade nacional, deve-se ter em conta que:

A identidade é a consciência de pertença a uma determinada categoria, i. e., "pertenço a uma categoria de indivíduos que se caracterizam especificamente por uma condição comum [...] e que se distingue de todos os outros por estes não o serem» (MATOSO 2003).

6 Renan (apud AMANTE 2011: 13) define a nação como «uma alma, um princípio espiritual em cuja criação se identificam elementos objectivos, mas se impõem os de carácter mais subjectivo, traduzidos no consentimento diário, no desejo de viver juntos, na vontade de perpetuar o valor do património que se recebeu de forma indivisa».

7 Assim, Smith (1997) define identidade nacional como o conjunto de valores constituído por um território, mitos e memórias históricas comuns, uma cultura de massa pública comum, direitos e deveres legais comuns e uma economia comum com mobilidade territorial para todos os membros. Nesta classificação de Smith, pode perceber-se a fusão de elementos de dois conceitos, muitas vezes, também confundidos entre eles: o estado e a nação.

8

Se «o Estado se refere exclusivamente a instituições públicas, diferenciadas e independentes de outras instituições sociais, que exercem um monopólio de coerção e 
extracção dentro de um determinado território - povo, território e poder político -, a nação exprime um laço cultural e político que une numa só comunidade política todos aqueles que partilham uma mesma terra de origem e uma cultura histórica comum». Destes dois conceitos de Smith (1997: 29), que apresentam alguns elementos comuns, decorre da velha questão sobre quem precede o outro - Nação ou Estado? - e que importância tem cada um para a existência do outro. Outra questão que se coloca é se é possível a existência de uma identidade nacional num «estado-não-nação».

9 Anthony Smith admite alguma sobreposição entre os dois conceitos, «dada a sua referência comum a um território histórico $\mathrm{e}-\mathrm{em}$ estados democráticos - o seu apelo à soberania do povo. Ainda que os estados modernos se devam legitimar como estados de nações específicas, o seu conteúdo e os seus pontos de divergência são bastante diferentes». Recorrendo a estudos de Walker Connor (1994), realizado no princípio dos anos 1970, o autor diz que apenas $10 \%$ dos estados da época podiam afirmar ser verdadeiros estados-nação, no sentido de que os limites do Estado coincidem com os da nação e que a população total do estado partilha uma única cultura étnica. Nesta ordem de ideias, Smith deixa entender que a maioria dos estados não são nações por não preencherem os elementos atrás enunciados.

10 Contudo, todos os estados aspiram ser considerados «estados-nação» por esta entidade, muitas vezes fictícia, representar a coesão nacional e a existência de um povo que se afirma como diferente do outro, através de uma memória colectiva, valores e significados comuns (MATOSO 2003). Por esta razão, acrescenta Smith, os estados tendem a limitar as suas pretensões de legitimidade à aspiração a uma unidade política e à soberania popular que, «mesmo as nações dos estados ocidentais, há muito estabelecidas, correm o risco de ser contestadas por comunidades étnicas existentes dentro das suas fronteiras» (op. cit.: 29).

\subsection{A nação étnica-territorial e a étnica-genealógica}

11 Este autor põe em relevo duas dimensões na abordagem do conceito nação: a étnicaterritorial e a étnica-genealógica, uma multidimensionalidade que, no entender de Smith, transformou a identidade nacional numa força tão flexível e persistente da vida e da política moderna, tendo permitido que ela se associasse eficazmente a outras ideologias e movimentos modernos sem perder as suas características. Dito de outro modo, a identidade nacional cultivada, quer numa, quer noutra dimensão, passou a ser a base de legitimação do poder político fosse qual fosse a ideologia ou o regime político em vigor. Hitler invocou a superioridade da raça ariana para tentar se vingar da humilhação que os aliados da Primeira Guerra Mundial impuseram à Alemanha. Durante a Guerra-Fria, os regimes totalitários em África, Ásia, América Latina e Europa do Leste, também, apregoaram a identidade comum para galvanizar a vontade nacional contra qualquer acção externa ou interna, hostil ao poder vigente. Agindo desse modo, «o apelo à identidade nacional tornou-se principal legitimação para a solidariedade e a ordem social dos nossos dias» (id., ibid.: 31).

Smith estrutura as duas dimensões em funções externas e internas. As primeiras têm a ver com as territoriais, económicas e políticas. Na função territorial, as nações definem, em primeiro lugar, um espaço social, dentro do qual os seus membros vivem e trabalham num território histórico onde todos veneram os mesmos antepassados. 
Trata-se de uma comunidade fixa no tempo e no espaço, proporcionando aos indivíduos centros sagrados bem como objectos de peregrinação espiritual e histórica.

$\mathrm{Na}$ económica, as nações comprometem-se à pesquisa de controlo sobre as riquezas territoriais, incluindo o potencial humano, enquanto politicamente, a identidade nacional sustenta o estado e os seus órgãos, ou os seus equivalentes pré-políticos nas nações que não possuem estados próprios. Smith classifica, como função política mais proeminente da identidade nacional, a legitimação de direitos e deveres comuns de instituições legais que definem o carácter e os valores peculiares da nação e reflectem os antiquíssimos costumes e práticas do povo.

Na dimensão interna (mais íntima para os indivíduos da comunidade), a mais óbvia é a socialização dos membros como nacionais e cidadãos, um processo permanente só conseguido através de escolas, meios de comunicação de massa, partidos políticos e forças militares e paramilitares. Como veremos adiante, a socialização dos membros da comunidade desempenha um múltiplo papel: serve para promover, exaltar e preservar a identidade nacional, ao mesmo tempo que produz uma cultura política, geoestratégica e geopolítica.

Assim, a identidade nacional, que consiste no facto de os iguais (os mesmos) serem diferentes dos outros, através de valores, símbolos, memória colectiva e território comum (MATOSO 2003), «é um poderoso meio para definir e posicionar pessoas individuais no mundo, através do prisma da personalidade colectiva e da sua cultura distinta. É uma cultura única e partilhada que nos permite saber "quem somos" no mundo contemporâneo» (SMITH 1997: 31).

O excerto acima remete-nos à questão inicial: é possível a existência de uma identidade nacional num «estado-não-nação» ou multiétnico, como é o caso da maioria dos Estados africanos?

Anthony Smith define um grupo étnico como «um tipo de colectividade cultural, colectividade essa que sublinha o papel de mitos de descendência e de memórias históricas, e que é reconhecida por uma ou mais diferenças culturais, como a religião, os costumes, a língua ou as instituições». Se atentarmos para esta definição, concluiremos que um grupo étnico equivale à nação, embora o primeiro venha a ser objecto de alterações e sirva muitas vezes para instrumento de subversão, como acontece com vários países africanos, ou ainda para evitar que as populações se unam em torno de um projecto contra uma força de ocupação, como aconteceu em vários territórios colonizados. ${ }^{1} 0$ segundo, considerado também um fenómeno cultural, muitas vezes, é uma criação do poder político com o fito de promover a identidade nacional e a consequente harmonização dos interesses nacionais.

Portanto, tanto a nação como a etnia são uma comunidade que se define pela pretensão do território, mas sobretudo pela construção simbólica - é história, é memória colectiva, assente em símbolos e mitos - e por um conjunto de normas (consuetudinárias ou formais) que regula a convivência dos seus membros.

\subsection{A «invenção» da nação}

19 Para Smith, o Estado e as elites políticas têm a responsabilidade de criação da nação, através da aglutinação dos vários vectores que unem os diferentes grupos e a rejeição dos que os distinguem. Ou seja, um grupo pode estar ligado por convivência e por consanguinidade, através de elementos subjectivos (mitos, lendas, a consciência 
colectiva e consciência nacional) e objectivos (recursos, população e posição geográfica).

Aliás, Henry Kissinger (2003: 189) é pragmático em relação a isso, quando diz que o Estado precede a nação e "tem de ir buscar a "consciência nacional" a uma pletora de tribos, grupos étnicos e, em muitos casos, a religiões diferentes» para construir a identidade nacional, fundada na nação, a nova nação, aquela que passará a ter nova memória colectiva, nos heróis, símbolos, significados e, sobretudo, um quadro legal comum.

21 Anthony Smith designa isso por «invenção» da nação, por surgir da via cívica territorial, em oposição e/ou posterior ao étnico genealógico. Naquele processo, o território constitui o elemento fundamental para a aglutinação de diversas etnias que passarão a invocar uma memória colectiva, símbolos, valores e, sobretudo, a preservação do seu espaço, «a terra dos nossos antepassados». O autor identifica duas vias para a criação dessas nações cívicas e territoriais:

1. O modelo dominante, no qual a cultura da comunidade étnica central do novo estado se torna o pilar mais importante das novas comunidades e identidades nacionais. Apesar de outras culturas continuarem a florescer, a identidade da comunidade política emergente é moldada pela cultura histórica da etnia dominante.

2. O modelo supra-étnico, onde não existe etnia dominante para subordinar a nova comunidade política (o Estado). Esta última via parece a mais adequada ao nosso objecto de estudo e daí que se torne fundamental para a nossa análise. Embora este modelo não tenha sucesso para vários estados como a Nigéria e Uganda, por ter dificuldade de retirar a lealdade dos indivíduos para com os seus símbolos, tem a virtude de se promover uma identidade política nacional que fará dos indivíduos detentores de uma memória histórica colectiva, embora não se perca a diversidade cultural que se vai esbatendo ao longo das várias gerações. Exemplos para ilustrar este facto abundam em África: a Tanzânia, o Ghana, o Egipto e inclusive a própria Angola, graças à legitimação de nação territorial («de Cabinda ao Cunene, um só povo e uma só nação») e da identidade política que a acompanha. Ou seja, a comunidade política desses novos estados preservam os limites do território deixado pela potência colonial (um espaço uno e indivisível), impondo nas elites dos diversos grupos étnicos o respeito pelas fronteiras físicas do país, embora, e quase sempre, esses limites físicos não estejam em conformidade com os limites étnicos. A base deste compromisso com o território, como sublinhou o autor, é a crença na importância da residência e da afinidade, por oposição à descendência e à genealogia. Ou seja:

«Viver em conjunto e estar enraizado num terreno e num solo particulares tornamse os critérios de cidadania e as bases de uma comunidade política. A nação é concebida como uma pátria territorial, o local do nosso nascimento e da nossa infância, a extensão do coração e do lar. É também o local dos nossos antepassados e dos heróis e das culturas, da nossa antiguidade. Daí que, do ponto de vista de um nacionalista territorial, seja bastante legítimo anexar os monumentos e os artefactos de civilizações anteriores no mesmo local, usurpando as suas conquistas culturais para diferenciar e glorificar a nação territorial» (SMITH 1997: 146).

Como se pode perceber do extracto acima, a construção (invenção) da nação supraétnica vai exigir da elite política a busca de elementos comuns para todos os grupos étnicos, entre os quais a idade de ouro, as conquistas heróicas, uma religião que esbata as diferenças e uma missão ontológica que abarque a memória estratégica (o que se pensa) e o pensamento estratégico (o que se deseja). Silva Ribeiro (2010) designa esta dimensão por base subjectiva que integra a tradição histórica, que dará origem à consciência nacional ou colectiva, e a filosofia política básica de governo que se traduzem numa concepção da vida para a sociedade política. 
23 A professora Fátima Amante (2011: 16) considera «as identidades nacionais permeáveis à mudança, capazes de influenciarem e de se deixar influenciar, pois, são abertas, relacionais em permanentes construção». Para a reprodução de identidade nacional, a autora sublinha a existência de duas dimensões fundamentais: de natureza objectiva (cultura, território, memórias históricas) e de natureza subjectiva, que compreende crença de pertença, bem como os contornos que se atribuem essa pertença. Assim, segundo ainda Fátima Amante, a nação impõe-se não apenas como uma comunidade imaginada, mas sobretudo como uma construção discursiva que é produzida e reproduzida, transformada e desmantelada discursivamente.

De acordo com o conceito, consagrado no final da Primeira Guerra Mundial pela orientação do então presidente norte-americano, Woodrow Wilson, era entendida como uma comunidade na identificação sociológica, e avaliada como a expressão mais sólida da solidariedade que orienta a decisão de suportar em comum as adversidades, os desafios, os projectos, mantendo-se assim na sucessão das gerações, e ambicionando a suficiência de meios, recursos e determinação para gerir politicamente, com independência, os seus destinos.

25 Segundo Lord Acton [i. e., John Emerich Edward Dalberg Acton, Baron Acton], foi o Estado que deu origem à Nação, e não a Nação que antecedeu o Estado, reservando assim uma intervenção determinante para a variável do poder político e da relação duradoura entre a dependência da população de uma sede do poder, e o seu envolvimento longo num projecto estratégico de governo (BEMBE 2013).

\subsection{A identidade nacional como pilar dos objectivos nacionais}

26 A conjugação da tradição histórica com a filosofia política, segundo o professor Silva Ribeiro (2010), resultam em móbeis políticos (motivações nacionais), elementos determinantes para a adopção de objectivos nacionais permanentes. «São eles que orientam a escolha, entre a multiplicidade dos objectivos políticos possíveis daqueles que irão ser prosseguidos em permanência pelo Estado, à luz dos fins últimos: os objectivos permanentes» (RIBEIRO 2010: 41).

27 Portanto, nesse exercício da busca de identidade nacional para a legitimação dos objectivos estratégicos de um Estado, uma multiplicidade de elementos serão fundamentais, dos quais se destacam a memória estratégica, o pensamento estratégico, as culturas política, estratégica e geopolítica, bem como um processo de socialização e comunicação política para a construção daquilo que se convencionou designar por coesão nacional.

28 A memória estratégica assume dois conceitos, introduzidos pelo antropólogo italiano Bernardo Bernardi (1974): antropema (memória individual) e etnema (memória colectiva). o primeiro caso consiste em orientações de indivíduos que, de tanta pertinência e carisma, podem representar o pensamento estratégico do colectivo. No caso de Angola, cita-se o exemplo de Agostinho Neto (primeiro presidente da República) cuja frase (tornadas palavras de ordem) - «Angola é e será por vontade própria trincheira firme da revolução em África» e «No Zimbabwe, na Namíbia e na África do Sul está a continuação da nossa luta» - é assumida hoje como base para a afirmação do estado angolano na região.

O etnema consiste na identificação de um povo a partir dos seus valores colectivos e, para o caso em apreço, é o conjunto de acções estratégicas de um povo ao longo da sua 
existência (BERNARDI 1974). Logo, a memória estratégica vai constituir o depósito de toda a informação relativa às acções estratégicas de um Estado quer seja de origem individual, quer seja colectiva, com o fito de construir uma doutrina que suporte os objectivos estratégicos assentes no pensamento estratégico da comunidade.

o pensamento estratégico é um somatório da construção identitária, da memória colectiva e da elite (a capacidade de impôr um pensamento). Ao contrário da memória estratégica, o indivíduo é actor do pensamento estratégico e não é autor. 0 pensamento estratégico, ainda que seja sistematizado por um indivíduo, vai traduzir sempre os valores ontológicos da sociedade - aquilo que se pensa e o que se deseja compreendendo, pois, uma cultura na base da qual o Estado orientará o seu comportamento estratégico. Daí que o sucesso de qualquer acção estratégica terá de assentar em três componentes estruturantes, interdependentes entre si: A cultura política, que nasce nos anos 1970 enquadrada, assenta numa definição mais alargada, segundo a qual os Estados só podem ter eficácia nas suas actuações se estiverem assentes nas bases de desenvolvimento político. Este conceito de desenvolvimento político assenta em três pilares: cultura política, socialização política e comunicação política. Os três pilares são de tal forma interdependentes que a ausência de um anula o outro. Ou seja, a socialização e a comunicação política cristalizam a cultura política, esta que, por sua vez, gera aquelas duas.

A cultura política é um conceito novo que surge nos anos 50 do século XX com os norteamericanos Gabriel Almond, Lucien Pye e Sidney Verba, enquadrada numa corrente sistémica, que lhe deu um sentido ligado às características e aos valores políticos inerentes a cada contexto político e potenciadores de diferenças de funcionamento do mesmo face a outros sistemas políticos (SANTO 2006). Pois, a partir da observação de Almond (1990), segundo a qual uma abordagem sistémica da investigação da cultura política tem a virtude de manter a sua análise firmemente enraizada na estrutura e desempenho do sistema político, compreende-se que a cultura política resulta de todo um conjunto de valores, símbolos sociais e políticos interiorizados pela sociedade política ao longo dos tempos.

32 Assim, a cultura política caracteriza um conjunto de representações simbólicas de valores, padrões de comportamento, atitudes e crenças, normas atinentes e distintivos de cada sistema político, gerando, por sua vez, a cultura cívica que traduz o fenómeno de relação e participação política percepcionado e vivido pelos cidadãos no âmbito de cada sistema político (SANTO 2006). Os dois conceitos estão intimamente ligados, podendo os dois confundir-se. Assim, da cultura política, segundo Paula do Espírito Santo, vão derivar a cultura paroquial, a cultura sujeita e a cultura participante.

Na paroquial, existe um baixo ou quase inexistente sentimento de identificação política dos cidadãos em relação ao Estado. Estes sentem-se mais próximos do poder local do que do nacional, não esperando nada deste último. Logo, não há discussão acerca dos assuntos políticos nacionais da escala nacional, sendo uma cultura própria das pequenas povoações. A paroquial corresponde à forma tradicional de organização de poder que se encontra nas sociedades tradicionais, onde os processos de organização e mobilização não são sofisticados.

34 Na sujeita ou de subordinação predomina uma atitude passiva dos cidadãos em relação à política, estando por isso bastante limitado e dependente a sua capacidade de influência dos órgãos de decisão. Os cidadãos vêem-se mais como sujeitos do que 
participantes na acção política, sendo os seus dirigentes uma minoria abastada que rege os seus interesses e coordena a vida política, económica e social.

Ao contrário das duas anteriores, na cultura política participante, os cidadãos interferem na condução pública da comunidade e têm o sentimento de participar na condução política dos seus interesses. Neste tipo de cultura promove-se a discussão sobre os assuntos políticos assim como a competência política, através de um sistema de informação, de meios de comunicação social e demais agentes de socialização, abertos e bastante funcionais - próprio das sociedades evoluídas.

O princípio de separação de poderes explica a sofisticação dessas últimas, ao contrário da paroquial onde as três funções se confundem. A cultura política de sujeição corresponde aos regimes totalitários, onde o cidadão participa de forma orientada em função dos objectivos da elite do poder. Nos estados democráticos, onde se verifica com maior nitidez a cultura política de participação, as instituições são legitimadas pela colectividade.

Contudo, a perenidade de uma cultura política vai permitir a manutenção de valores e ideais da sociedade ao longo do tempo, um objectivo só possível de ser alcançado através da socialização política. Ou seja, o conjunto de representações simbólicas, de valores, padrões de comportamento, atitudes e crenças ligados à formação de um Estado, Nação ou Comunidade serão interiorizados e interpretados por cada indivíduo através de um processo de socialização. Este processo, como preceituou Montesquieu (1714-1726), concretiza-se através da família (nossos pais), da escola (nossos professores) e pelo mundo. Este último - compreende grupos de amigos, grupos de pressão, partidos políticos, meios de comunicação social -, muitas vezes, contradiz-se com os dois primeiros canais de socialização.

Socialização política é o processo pelo qual o indivíduo interioriza ao longo da sua vida valores essenciais da cultura política. Paula do Espírito Santo (2006: 120) define socialização política como «um caminho ou percurso que de forma natural, ou seja, de maneira corrente ou informal envolve o indivíduo a partir do nascimento e termina com a sua morte, proporcionando a sua integração e capacitando-o de instrumentos de envolvimento $e$ actuação sociopolítica que the permitam desenvolver e desempenhar a sua capacidade de cidadania». Deste conceito, pode reter-se o seguinte:

a. 0 indivíduo, enquanto membro da sociedade política, apreende os valores que superintende a comunidade desde a nascença até à morte, obviamente através de diferentes elementos de socialização, conforme a idade e a maturidade política;

b. A socialização permite a integração do indivíduo na comunidade, tornando possível a sua identificação com os valores e ideais da sua colectividade;

c. O indivíduo é capacitado para tornar-se num elemento activo com capacidade para participar, de forma consciente e dinâmica, na realização dos fins da sua Nação ou Estado cidadania.

Hague et al. (apud SANTO 2006) sintetiza este conceito, dizendo que a socialização política é o processo através do qual aprendemos acerca da política. Esta aprendizagem diz respeito a emoções, identidades e competências assim como de informação.

Sendo assim, as principais dimensões de socialização compreendem o que as pessoas aprendem (o conteúdo), quando o aprendem (tempo e sequência) e de quem o aprendem (o agente). 
41 As paradas escolares destinadas ao içar da bandeira sob o entoar do hino nacional, o recrutamento militar, as comemorações de actos heróicos em homenagem a personagens históricos, os momentos de exaltação à pátria e as visitas a monumentos históricos, os debates nos media e a participação em actos eleitorais constituem acções de socialização política cujo corte pode representar custos imensuráveis na identidade política nacional e, por conseguinte, no conceito estratégico nacional. Trata-se de valores estruturantes (mores) de uma sociedade, que não podem ser ignorados pela socialização, já que tudo o que não conste da socialização é desvalorizado e perde-se ao longo do tempo.

A par da socialização, a comunicação política surge como elemento assessório àquele, existindo entre ambas, uma ligação construída a partir de meios ou mecanismos de formação potenciados na primeira (cultura política) e representados e expostos na segunda - a comunicação política que Paula do Espírito Santo prefere utilizar o termo redutor «opinião pública». A comunicação política, portanto, corresponde a todos os meios que a sociedade dispõe (partidos políticos e meios de comunicação social e redes sociais, a sociedade civil entre outros) para passar os valores fundamentais do Estado ou Nação.

43 Paula do Espírito Santo propõe a existência de dois meios de formação de opinião pública: informais e formais. Os primeiros dizem respeito e estão associados de maneira intrínseca à formação da condição social da natureza humana. Os meios formais pautam-se por um carácter dirigido, planeado, técnico e tecnológico de formação sistémica, estando a sua configuração dependente das características de cada sistema político.

44 Assim:

- Os meios informais de cultura e comunicação política compreendem as estruturas sociais (família, escola, religião, instituições e organização), as características conjunturais de índole histórico-cultural, os boatos, os mecanismos psicológicos e o simbolismo associado a todo o tipo de manifestações humanas a partir do momento do nascimento;

- Os meios formais de formação da cultura política e da comunicação política (opinião pública) são, entre outros, a comunicação social, o livro, a propaganda e os inquéritos e sondagens de opinião. O Bolonha e o Erasmus são dois instrumentos bem conseguidos para a socialização e comunicação políticas visando a criação do cidadão europeu.

Como referimos atrás, a construção de uma identidade nacional não é um processo espontâneo e alheio à elite política. Esta, procurando uma coesão nacional que permita a preconização dos seus objectivos, manter todos os mecanismos necessários à promoção de uma identidade comum, que gere em todos o sentimento de pertença e a consciência nacional, fazendo com que cada membro da comunidade lute voluntariamente pela preservação do seu território comum, dos valores patrimoniais simbólicos e por toda a herança dos seus antepassados comuns. Esta heterogeneidade, que se consolida à medida que os indivíduos cristalizam a sua cultura política, propiciará o nascimento de uma cultura estratégica.

46 Como disse o professor António Silva Ribeiro (2010), todo Estado quando cresce diversifica e internacionaliza os seus interesses estratégicos, a vontade de todos membros de um Estado serem distintos e resistirem à acção e/ou modificar o comportamento dos contrários poderá aumentar. A maioria dos cidadãos norteamericanos certamente estará disposta, a qualquer custo, a impedir uma eventual 
ameaça dos russos e como estes se juntarão à volta dos seus líderes sempre que aqueles demonstrarem uma atitude hostil ao seu país. Esta predisposição de um povo aceitar a narrativa da guerra, o sacrifício pela honra e dignidade da sua identidade chama-se cultura estratégica.

O termo cultura estratégica foi utilizado pela primeira vez em 1977 por Jack Snyder, para se referir a um conjunto de atitudes e crenças que guiam e circunscrevem o pensamento sobre questões estratégicas, que influenciam a maneira como estas questões são formuladas e articulam o vocabulário e os parâmetros perceptuais do debate estratégico (JOHNSTON 1995: 5).

Ao fazer uma revisão bibliográfica dos estudos que abordavam o pensamento estratégico a partir de uma perspectiva cultural, Alastair Johnston utilizou a metáfora das «três gerações», tendo em conta a proposta conceptual adoptada pelos seus autores. A primeira geração de estudos sobre cultura estratégica dedicou-se primordialmente a explicar por que os governos soviético e norte-americano aparentemente pensavam de forma diferente a respeito da estratégia nuclear. Os autores da primeira geração atribuem as diferenças entre os países a variações em factores tais como experiências históricas arraigadas, cultura política e geografia (MARQUES 2008).

Para Johnston as principais fragilidades teóricas da primeira geração são:

a. $O$ determinismo mecanicista ao tratar da relação entre cultura e comportamento, o que dificulta a avaliação da relevância causal da cultura estratégica;

b. A forma simplista como a cultura estratégica nacional é definida, excluindo a possibilidade da existência de mais de uma cultura estratégica num mesmo país (JOHNSTON 1995: 37-39).

50 A segunda geração de estudos sobre cultura estratégica rejeita o determinismo mecanicista dos seus antecessores no que diz respeito à relação entre cultura e comportamento. Os autores desta geração partem da premissa de que há uma grande diferença entre a política declaratória - o que os líderes políticos pensam ou dizem que estão a fazer - e os verdadeiros motivos pelos quais os políticos adoptam determinadas posturas. Neste sentido, a cultura estratégica é vista como um instrumento dos grupos políticos hegemónicos uma vez que o discurso oficial dos seus mentores de política militar esconderia os verdadeiros motivos pelos quais este discurso é produzido, qual seja, defender os interesses particulares destes decisores (MARQUES 2008). Johnston reconhece o avanço teórico da segunda geração, que inova ao mostrar a disjunção entre a cultura estratégica ou discurso simbólico e o comportamento político, mas aponta alguns problemas metodológicos nesta abordagem:

a. Os estudos da segunda geração não esclarecem como a cultura estratégica pode influenciar o comportamento dos autores de política, pois, se a Política de Defesa Nacional de um país é reflexo dos interesses particulares dos grupos que a formulam, qual é o papel da cultura estratégica neste processo? Neste caso, pode-se argumentar que a Política de Defesa Nacional é determinada, em última instância, pelos interesses e não pela cultura estratégica. Uma explicação que um analista realista aceitaria sem maiores questionamentos.

b. A segunda geração também não responde satisfatoriamente por que os países adoptam posturas estratégicas diferentes ou semelhantes. Pode-se argumentar que o discurso simbólico de um grupo de autores de política legitima certas opções estratégicas e deslegitima outras. As opções estratégicas legítimas ou ilegítimas variariam então de acordo com a cultura estratégica de cada país. Mas, ainda de acordo com Johnston (1995: 39-41), como explicar que países com culturas estratégicas diferentes compartilhem opções estratégicas semelhantes? 
c. Já a terceira geração de estudos sobre cultura estratégica, que integram nomes como Johnston e Kier, busca um maior rigor metodológico. Na sua maioria, os autores da terceira geração esforçam-se para elaborar um conceito de cultura estratégica que possa ser testado através de uma metodologia positivista. Nesta perspectiva, a cultura é vista como uma variável independente e o comportamento político como uma variável dependente. Johnston define cultura estratégica do seguinte modo:

«A cultura estratégica como um "sistema de símbolos" compreende duas partes: a primeira consiste em pressupostos básicos sobre a ordem do ambiente estratégico (isto é, sobre o papel da guerra nos assuntos humanos se é aberrante ou inevitável), sobre a natureza do adversário e a ameaça que ela representa (soma-zero ou de soma positiva), e sobre a eficácia do uso da força (sobre a capacidade de controlar os resultados e eliminar as ameaças e as condições em que o uso da força é útil). Estes compreendem o paradigma central de uma cultura estratégica. A segunda parte da cultura estratégica consiste em suposições num nível mais operacional sobre o que as opções estratégicas são os mais eficazes para lidar com o ambiente de ameaças, conforme definido pelas respostas a estes três conjuntos de perguntas. Estes pressupostos de nível inferior devem decorrer logicamente do paradigma central. É neste segundo nível que a cultura estratégica começa a incidir directamente sobre as escolhas comportamentais. Assim, as componentes essenciais ou referentes empíricas de uma cultura estratégica aparecerão sob forma de um limitado conjunto, classificados de grandes preferências estratégicas, que são consistentes em todos os objectos de análise e persistente ao longo do tempo. Eles não são, portanto, necessariamente sensíveis a mudanças em variáveis não culturais como tecnologia, ameaça, ou a organização» (JOHNSTON 1995: 37-38).

51 Neumann e Heikka são pragmáticos quando afirmam que a metáfora das três gerações criada por Johnston acabou por voltar-se contra o seu próprio criador. Para eles, o principal «defeito» herdado por Johnston da primeira geração é a decisão de utilizar uma metodologia positivista, quando os antropólogos e sociólogos encaram a cultura como fenómeno constitutivo e não uma variável independente que pode ser isolada (NEUMANN e HEIKKA 2005:9). Para superar as limitações metodológicas da terceira geração, Neumann e Heikka (2005: 18) entendem cultura estratégica como «um sistema de formação de declarações e práticas de doutrinas, relações civis-militares e aquisições».

O conceito de cultura estratégica proposto por Neumann e Heikka considera as interconexões entre o contexto internacional e a dinâmica doméstica, definida pelos actores políticos e as suas práticas. Por sua vez, Snyder (apud ROMANA 2013) define a cultura estratégica como o somatório de ideias, respostas emocionais e padrões de comportamento que os membros da comunidade estratégica nacional dos Estados Unidos da América (EUA) adquirem num contexto do desenvolvimento de uma estratégia nuclear para fazer face à ameaça nuclear soviética. Jack Snyder, que analisou uma série de estudos etnográficos sobre guerras em sociedades sem Estado, constatou que a cultura como variável independente não é capaz de explicar os conflitos armados por ele seleccionados. Snyder (2003) defende uma análise que leve em conta a interacção entre as variáveis materiais, institucionais e culturais. Mas, como se pode perceber, o conceito de Snyder, nascido no contexto de guerra-fria, precisa de ser adequado ao contexto específico, já que cada Estado, enquanto actor das relações internacionais exposto a uma concorrência incessante com os seus pares, dispõe de uma cultura estratégica.

53 O professor Heitor Romana (2013: 44) considera a cultura estratégica como «o conceito operacional que diz respeito aos valores, símbolos e padrões culturais que modelam a posição dos povos e em especial das suas elites em relação à guerra, e à forma como é garantida a segurança 
nacional - instrumentos adoptados, mobilização da sociedade, posição do Estado na hierarquia dos poderes mundiais e capacidades de afirmação de uma estratégia nacional». Para nós, este conceito parece-nos o mais adequado, por apresentar a cultura estratégica como uma variável que ajuda a perceber como é que uma cultura estratégica é desenhada, como as forças armadas estão organizadas em diferentes países e como é feita a hierarquia de comando. E como é que este povo/sociedade aceita a narrativa da guerra? Isso subentende-se, pois, «dizem respeito aos factores culturais que ao longo dos tempos vão influenciando e determinando a percepção que os Estados e as suas instituições têm das suas potencialidades críticas, políticas, militares, culturais e científicas» (ROMANA 2013: 45).

Entretanto, como refere Romana, não se pode construir e operacionalizar um conceito de cultura estratégica sem se ter em conta os conceitos de cultura geopolítica, imaginação geopolítica, tradições geopolíticas e discurso geopolítico.

Para o autor, a cultura geopolítica diz respeito ao conjunto de práticas que caracterizam a identidade, a posição e o papel de um estado num sistema de estados, abarcando as instituições do estado - as suas experiências históricas e raízes geográficas - as redes de poder dentro da sociedade, debates sobre a identidade nacional, prevalência de uma imaginação geopolítica colectiva, as tradições geopolíticas e o processo institucional de elaboração da política externa do estado (ROMANA 2013: 45). A partir desta definição percebe-se que a cultura geopolítica poderá ser influenciada pela imaginação geopolítica e pelo discurso geopolítico. A primeira corresponde às imagens, conceptualizações e discursos que são prevalentes na sociedade e no contexto geopolítico em que o estado está inserido - a qual civilização ou comunidade de estados o cidadão crê que o seu estado pertence? Como é que o povo situa o seu país e a sua identidade num mundo de identidades em competição? o discurso geopolítico compreende as articulações e codificações narrativas que estruturam uma cultura geopolítica, numa aproximação e uma hermenêutica operativa. A articulação do discurso e da imaginação geopolíticas, de forma persistente e permanente, resultará na tradição geopolítica, definida pelo professor Heitor Romana (2013: 45) como o conjunto de escolas do pensamento geopolítico, que enquadram a alta cultura de uma geopolítica de um estado, sendo «cada tradição uma parte do pensamento em que assenta a identidade de um estado, o interesse nacional $e$ as prioridades da política externa», o que, em síntese, pode se designar por conceito nacional estratégico.

\subsection{0 conceito estratégico}

Como facilmente se pode perceber, a cultura política, a cultura estratégica e a cultura geopolítica são valores interligados, podendo ser solidificados à medida que o Estado aprimora as suas fontes de poder, ao mesmo tempo que favorecem a construção de uma estratégia nacional exequível.

O que é então a estratégia?

Depois de analisar uma multiplicidade de conceitos, Abel Cabral Couto (1988: 209) define estratégia como "a ciência e a arte de desenvolver e utilizar as forças morais $e$ materiais de uma unidade política ou coligação, a fim de se atingirem objectivos políticos que suscitam, ou podem suscitar, a hostilidade de uma outra vontade política».

Deste conceito, pode inferir-se que a estratégia aplica-se numa dualidade hostil (disputa) que se pretende resolver por meio da aplicação de todos os meios possíveis para se atingir a eficácia máxima (a vitória de A contra a derrota de B). Ou seja, sem 
inimigo, real ou potencial, não há estratégia. A estratégia consiste numa luta em que uma vontade procura vencer a vontade do antagonista. Abel Couto alerta que só em sentido figurado se pode falar em estratégia desportiva ou empresarial ou em confronto entre polícia e ladrões, na medida que o termo estratégia, na sua verdadeira acepção só se relaciona com a luta entre unidades políticas.

De forma sintética, António Silva Ribeiro (2010) define a estratégia como um processo que define objectivos, meios e tempo para desarticular a força do oponente. Para a sua eficácia, a estratégica socorre-se a seis elementos essenciais que concorrem para a sua eficácia nomeadamente: a modalidade de acção (o conjunto de manobras que visa agir sobre os pontos fracos do oponente e ultrapassá-lo, envolvê-lo, cortar as suas bases de reabastecimento, desorganizá-lo e desagregá-lo de tal forma que perca as suas capacidades combatentes (Castex apud RIBEIRO 2010: 98); factores de decisão, que integram o objectivo fixado pela política, o meio (lugar), os meios de coacção, o tempo e o contrário; níveis de decisão (responsáveis, subordinados e laterais); princípios gerais (importância do objectivo, economia de esforço); vantagem estratégica (visa alterar a relação de forças entre os actores com base na melhor articulação dos factores de decisão) e provas de estratégia (que consistem na avaliação da adequabilidade, exequibilidade e da aceitabilidade da estratégia). Em caso da estratégia integral - de um Estado - esses elementos integraram obviamente aquilo que se designa por Conceito Nacional Estratégico.

61 Silva Ribeiro (2010: 56 ) define o conceito nacional estratégico como uma grande ideia estratégica de materialização dos objectivos nacionais permanentes, adequada ao ambiente externo e interno, destinada a garantir a manutenção do país numa posição favorável, de tal forma que seja difícil aos seus contendores provocar-lhe prejuízos.

Deste conceito pode reter-se o seguinte:

1. 1. Como grande ideia estratégica, deve ter em atenção o potencial estratégico, bem como realizar acções que visem transformar este potencial em vantagem estratégica.

2. Para isso, o estrategista deverá estudar, avaliar e compreender a conjuntura externa e interna, para delas, conjugada com os factos do passado, poder obter a vantagem estratégica. Aliás, Ribeiro apresenta um esquema, fundado na matriz SWOT, bastante elucidativo: empregar potencialidades para explorar eventualidades (acção ofensiva); empregar potencialidades para superar problemas (acção defensiva); explorar eventualidades para corrigir vulnerabilidades (acção de manutenção), bem como corrigir vulnerabilidades para superar problemas (acção de retirada).

3. Esta operação deve resultar na manutenção do país numa posição favorável capaz de impedir prejuízos provenientes dos seus contendores, desde que o alinhamento da apreciação da situação internacional e da apreciação nacional efectuado na etapa da explicação da conjuntura, a formulação dos cenários internacionais e nacionais alternativos a longo e a médio prazos e a análise da interacção dos cenários nacionais com os vários cenários internacionais seja feito com o talento e o génio estratégico (RIBEIRO 2010).

63 Contudo, a decisão sobre a doutrina e atitude estratégica a ser adoptado por um Estado dependerá dos meios que, em todos os sectores, materializam as suas possibilidades. São estas possibilidades que se designam por potencial estratégico. Couto (2008) defineo como o conjunto das forças de qualquer natureza, morais ou materiais, que um Estado pode utilizar em apoio à sua estratégia. As forças num potencial estratégico podem ser classificadas: a) quanto à natureza, por materiais ou tangíveis ou morais ou intangíveis; b) quanto à situação podem ser imediatamente disponíveis ou latentes. Estas últimas 
podem estar disponíveis depois de activação, disponíveis depois de conversão, disponíveis depois de desenvolvimento ou exploração e disponíveis hipoteticamente.

Para fins do nosso estudo, importa apenas falar dos dois tipos de forças (materiais e morais). As forças materiais exprimem valores concretos, como os efectivos militarmente organizados, as quantidades de armamento, os recursos humanos, económicos e financeiros, o meio físico e os meios tecnológicos. As forças morais exprimem valores abstractos, entre as quais figuram a capacidade de organização, a qualidade dos chefes civis ou militares, o patriotismo, a capacidade de sacrifício e de adaptação a situações novas, a consciência que a população e o seu governo têm das possibilidades das suas forças materiais (COUTO 1988).

Nenhuma estratégia pode vincar sem a conjugação das duas forças, das quais a identidade nacional ocupará um papel preponderante, porque é dela que advém o patriotismo, a capacidade de sacríficio e a de adaptação à situações novas, bem como a consciência da população e do seu governo na utilização racional das forças materiais. Podemos mesmo arriscar a metáfora de que as forças imateriais do potencial estratégico constituem a base espiritual para uma acção estratégica que pretende reduzir as vulnerabilidades e contornar as ameaças.

66 Assim, o potencial estratégico é um somatório de forças materiais - potencial mássico - e influenciado por um elemento dinâmico - o potencial dinâmico -, correspondente às forças morais ou intangíveis. Beaufre apresentou a seguinte fórmula:

$67 \mathrm{~V}=\mathrm{KYF}$, onde o $\mathrm{F}$ representa as forças materiais, $\mathrm{Y}$ as forças morais e $\mathrm{K}$ é um factor variável que decorre das circunstâncias do momento (BEAUFRE 2004). Nesta fórmula vê-se o predomínio da correlação das duas forças que, no entanto, podem ser influenciadas pelas conjunturas nacional ou internacional que, muitas vezes, acabam por pôr em causa a consistência das forças materiais e morais.

\section{Angola: identidade nacional na construção de um conceito estratégico}

68 Como a maioria dos países africanos, Angola é um estado multiétnico cujas fronteiras físicas divergem com as fronteiras étnicas, fruto da conferência de Berlim (1884-1885), que delimitou os territórios em função da vontade das potências coloniais, sem ter em conta as fronteiras étnicas. São áreas etnolinguísticas de Angola: Ovimbundu, Ambundu, Bakongo, Lunda-Cokwe, Ngangela, Nyaneka-Khumbi, Herero, Oxiwambo e Ocindonga, Kwisi, Kwepe e Kung-Khoi-Khoi (REDINHA 2009; KAJIBANGA 1999 e 2000; NGONDA 1994).

69 Ao mesmo tempo que não existe um grupo étnico maioritário, sendo os mais representados demograficamente os grupos Ovimbundu, Ambundu, Bakongo e Cokwe - o que favorece, como vimos atrás, a construção de uma identidade nacional -, a maioria das etnias de Angola (com excepção dos Ambundu e Ovimbundu que nascem e morrem no território nacional) é transnacional, tendo membros (súbditos) em países limítrofes como Congo Democrático, Congo, Zâmbia e Namíbia. Para muitos autores, esta situação encerra uma ameaça latente para a soberania nacional e a construção de uma identidade nacional.

70 A continuidade da etnia Bakongo (das províncias angolanas do Zaire, Uíje e Cabinda) ${ }^{2}$ para os dois Congos e Gabão é considerado um factor de eventual instabilidade para 
Angola. Uma mudança na sede do poder em Kinshasa que, em aliança com o governo rwandês, ${ }^{3}$ seja hostil ao governo de Luanda, pode impulsionar a reactivação de um grupo separatista na província de Cabinda ou a criação de um movimento subversivo baseado no reino do Congo para criar um Estado de base étnica bakongo que, no passado, tinha a sua capital em Mbanza Kongo (província do Zaire). Esta situação criaria uma desarticulação económica e social profunda em Angola, uma vez que todo o petróleo produzido em Angola advém das províncias de Cabinda e do Zaire.

71 Uma investida para este fim já foi feita antes e depois da independência quando o presidente Mobutu apostou fortemente na Frente Nacional de Libertação de Angola (FNLA) e na União Nacional para a Independência Total de Angola (UNITA), depois de aquela se ter mostrado incapaz de levar a cabo as suas acções contra o governo de Angola (SÁ 2011). Aliás, não foi por acaso que a Frente de Libertação de Cabinda (FLEC) sempre beneficiou de apoio dos dois Congos que, claro está, sempre mostraram interesse nos recursos energéticos dessa região. No caso da RDC, acresce-se a necessidade de ampliar a sua entrada pelo mar com eventual desintegração de Cabinda do território angolano.

Conforme o demonstra Miguel Domingos Bembe (2013), alguns estados, como a França, tendem a recorrer eventualmente aos países limítrofes, mais exactamente ao CongoBrazzaville, para tentar concretizar anarquicamente os seus interesses petroeconómicos inatingíveis, numa estratégia de procuração, construída segundo lógicas geopolíticas e geoestratégicas, e Cabinda, estando dissociada territorialmente de Angola, poderia ser rapidamente engolida pelos Congos vizinhos.

73 Além dos dois Congos (ao Norte), Angola tem nas duas restantes fronteiras terrestres (Leste e Sul) duas frentes estratégicas que, pelas mesmas situações já atrás apontadas, podem transformar-se em fontes de instabilidade para Angola.

74 No leste (fronteira com a Zâmbia), onde as relações entre os dois Estados nunca foram estáveis, há a possibilidade de o governo zambiano ajudar os Luchazes (um grupo étnico com raízes no território angolano e que se estende para a Zâmbia), que podem ser utilizados para a criação de um partido político ou uma força subversiva que reivindique a separação das Lundas e Moxico, uma região tradicionalmente diamantífera, mas com um nível de desenvolvimento muito abaixo do das províncias do litoral e do centro e sul do país. Este facto, aliás, tem constituído o argumento do PRS Partido de Renovação Social (o partido cujos fundadores são oriundos dessa região) que, talvez por esta razão (ao contrário de todos os outros que surgiram com o multipartidarismo), nunca esteve fora do Parlamento desde as primeiras eleições multipartidárias, ocorridas em 1992. Este partido é o único que defende o federalismo para Angola, contrastando com a ordem constitucional que estabelece um estado unitário descentralizado (com poderes autarcas). ${ }^{4}$ Desta forma, a Zâmbia, que não tem saída para o mar, pode encontrar neste factor uma oportunidade para criar um instrumento válido no sentido de desestabilizar Angola. Aliás, a Zâmbia, além de ter sido, através do seu primeiro presidente Kenneth Kaunda, o elo da diplomacia a favor da UNITA junto do governo de Gerald Ford nos EUA (SÁ 2011), foi uma importante sede de apoio para esse movimento subversivo, quando tinha a sua base no leste de Angola (na província do Kwandu-Kuvango). Trata-se do momento em que a UNITA era apoiada pela África do Sul, Zaïre (actual RDC) e a Zâmbia numa posição menos evidente. Ao sul, a Namíbia pode vir a ser outra fonte de tensão contra Angola, caso surja um outro governo hostil ao Estado angolano. 
75 A Namíbia é um país que depende de Angola em termos de energia e água a partir do rio Cunene (perto da fronteira com esta antiga conhecida por Sudoeste Africano), tendo por isso muitas razões para fomentar uma rebelião dentro do seu território através de «súbditos» do reino kwanyama, para reivindicar a separação do seu território cujo reino se encontra igualmente no território angolano, ${ }^{5}$ a poucos quilómetros da fronteira. Este projecto de anexação seria concretizável com um eventual surgimento de um governo também hostil ao Estado angolano na República de África Sul que, aliás, com a Namíbia, apenas ressuscitariam as aventuras bélicas da Guerra-Fria, desta vez, através de activistas subversivos, filhos do espaço sociocultural kwanyama. Em Agosto de 1999, as Forças Armadas Angolanas (FAA) ajudaram a abortar uma tentativa de secessão da faixa do Caprivi, quando um grupo de guerrilheiros autodenominado Kaprivi Liberation Army (KLA) atacou e exigiu a separação da Namíbia e que, segundo o governo namibiano, estaria a ser ajudado por guerrilheiros da UNITA.

Consciente deste factor de instabilidade, como consequência da Conferência de Berlim (1884-1885), que estabeleceu as fronteiras dos países africanos sem ter em conta as fronteiras culturais, o poder político angolano aposta, desde a independência do país em 1975, na construção de uma identidade nacional angolana, tendo para isso criado desde elementos simbólicos - bandeira, insígnia, hino nacional, slogans, monumentos, estátua aos heróis locais - até a elementos materiais (instituições, constituição formal, entre outros valores). Esta aspiração por uma identidade nacional sólida passou a fazer parte da poesia, do cancioneiro nacional, dos selos e da moeda que nas suas duas faces apresentam a paisagem, bem como outros locais de importância histórica ou cultural dos vários povos que constituem o território nacional. o próprio hino nacional é um factor integrador e mobilizador para os desafios de um mosaico cultural que pretende ser um povo uno e indivisível com projecto para a sua afirmação no contexto das nações:

Ó Pátria, nunca mais esqueceremos

Os heróis do quatro de Fevereiro.

ó Pátria, nós saudamos os teus filhos

Tombados pela nossa Independência.

Honramos o passado a nossa História,

Construindo no trabalho o homem novo.

Honramos o passado a nossa História,

Construindo no trabalho o homem novo

Angola, avante!

Revolução, pelo Poder Popular!

Pátria Unida, Liberdade,

Um só Povo, uma só Nação!

O Hino Nacional da República de Angola constitui verdadeira base de um conceito nacional estratégico, que apela para honradez dos símbolos comuns, remetendo a reflexão para a idade de ouro (a independência) e o passado histórico que une os membros do Estado. Nota-se, nos seus versos, a exaltação patriótica de Angola, não só enquanto espaço territorial, mas também enquanto valor patrimonial herdado dos antepassados. Este sentimento patriótico e a aspiração por uma identidade comum elevam-se no refrão em que, repetidas vezes, se apela para a unidade e liberdade, com a construção de «Um só Povo, uma só Nação».

Por sua vez, o texto constitucional angolano confere relevo à construção de uma identidade nacional dinâmica que defenda a paz e o progresso social. 0 artigo 11.. , no seu n.. 1, estabelece: «A República de Angola é uma Nação de vocação para a paz e o progresso, 
sendo um dever do Estado e um direito e responsabilidade de todos garantir [...], a paz e a segurança nacional».

79 Assim, a Constituição da República de Angola (CRA) eleva a Nação a fundamento, finalidade e limite do poder político, ao mesmo tempo que serve de motivação para a construção e consolidação de uma identidade nacional.

Com efeito, na mesma CRA, notam-se outros pressupostos que podem dinamizar a construção da Nação, quando no artigo 8. se define a República de Angola como «um Estado unitário que respeita, na sua organização, os princípios da autonomia dos órgãos do poder local e da desconcentração e descentralização administrativas». Apesar do seu território extenso (1.24.700 $\mathrm{Km}^{2}$, superior ao da Alemanha e de Espanha juntos, só para citar estes) e com uma população etnicamente diversificada, o poder político angolano encontrou na unicidade do Estado um dos instrumentos basilares para impedir que as diferenças não se sobreponham às semelhanças entre as diversas comunidades étnicas que constituem o território nacional.

81 Portanto, como se pode inferir, nos textos acima citados assenta a filosofia política do estado angolano (o que se deseja) no que diz respeito à construção da identidade nacional que, como ficou assente atrás, sempre constituiu e continuará a constituir a preocupação do aparelho do poder político que vê na coesão nacional a base (de exigência e de apoio, com múltiplas expectativas) para a manutenção da soberania e a projecção dos interesses do Estado.

82 Contudo, como refere Miguel Bembe (2013), três correntes de políticos e estudiosos angolanos divergem em relação à existência ou não de uma nação em Angola.

83 Na primeira corrente, destaca-se o nome de Agostinho Neto que considera que as várias nações que habitam o território «estão hoje fundidas numa única nação angolana» (NETO 1980: 47).

84 Na segunda corrente, pontifica o nome de Paulo de Carvalho (2007), a quem se junta Carlos Feijó (2001). Para esta corrente, não existe ainda uma nação angolana, por, para o primeiro, ainda não existir um sentimento de consciência nacional e, para o segundo, estar desprovida de uma cultura angolana assente num substrato sociocultural bem como num sistema de referências sociais. A última corrente, desenvolvida por Víctor Kajibanga (apud FEIJÓ 2001), sugere que a nação angolana é um projecto nacional do Estado, que está em formação e afirmação. Para efeitos da presente abordagem, vamos adoptar esta última corrente por ser mais construtivista e que está de acordo com uma das teses de Anthony Smith adoptada para esta análise.

85 A primeira, enquadrada mais numa narrativa política do que científica, constitui o fundamento do discurso de mobilização das bases de apoio para um Estado que surge através de uma luta contra a dominação colonial e que busca na coesão nacional a força para a sua afirmação tanto do ponto de vista interno quanto do ponto de vista internacional. Daí que seja a narrativa adoptada pela constituição e por outros símbolos que caracterizam a República de Angola (bandeira, insígnia e hino nacional).

86 Na segunda corrente, pelo seu carácter pedagógico, importa visitar a tese de Paulo de Carvalho (2008), segundo a qual para que haja Nação em Angola deve consolidar-se a consciência nacional, o que pressupõe:

a. A dignificação do angolano comum, que tem de passar a sentir-se cidadão;

b. A eliminação de assimetrias na relação do indivíduo com o Estado;

c. Uma mais justa distribuição do rendimento nacional; 
d. Um maior investimento no acesso ao conhecimento.

87 Paulo de Carvalho constata a existência de um forte grau de patriotismo em Angola, o que se contrasta com a existência de consciência étnica em detrimento da consciência nacional. Para ele, quer no momento de luta de libertação nacional, quer no momento da construção do Estado angolano, não houve esforços concretos para a construção de uma identidade nacional.

«A luta de libertação do jugo colonial em Angola forjou um "nacionalismo anticolonial", que não era um verdadeiro nacionalismo, por estar ligado somente a uma elite. Esse nacionalismo anticolonial não possibilitou a criação de uma verdadeira nação, apesar de o discurso político ter apontado nessa direcção» (CARVALHO 2002: 3-4).

Outro factor a considerar na análise é a imposição política de existência de nação em Angola, feita no decurso do sistema monopartidário da 1. epública (1975-1991). Com a abertura democrática a partir de 1991, os angolanos começaram a fazer jus às diferenças que os separam (sejam étnicas ou raciais, sejam regionais ou religiosas), o que constitui sério travão à consolidação da identidade nacional.

O autor aponta duas dificuldades na formação de uma consciência nacional, nomeadamente a existência de dúvidas sobre o espaço geográfico de cada grupo étnico e de pequenos grupos que não se consideram enquadrados numa etnia, mas se consideram etnias à parte.

O primeiro caso tem a ver com as pessoas que, mesmo não estando no território da sua etnia, se mantém numa ligação espiritual com esse espaço geográfico dos seus antepassados. Exemplo disso são as populações que, devido à procura de melhores condições de vida e, mais tarde, por causa da guerra, instalaram residências nos grandes centros urbanos, muitas vezes em função da sua proveniência étnica. Luanda constitui o exemplo mais paradigmático desta abordagem.

91 No segundo caso, trata-se da possibilidade de desintegração de comunidades étnicas mais amplas (pouco provável) e o não reconhecimento, por parte dos grupos étnicos menores, da anexação espacial pelas comunidades étnicas maiores. Tanto um como o outro caso não constituem entrave para a criação de uma identidade nacional por parte do poder político, pelo contrário, podem favorecer a construção de uma identidade maior à simples consciência local.

Aliás, não existe por parte do poder político um reconhecimento da especificidade histórico-cultural das diversas comunidades étnicas que habitam o território de Angola (KAJIBANGA 2003), o que em parte pode, a longo prazo, contribuir para a cristalização de uma identidade nacional assente, portanto, em símbolos, monumentos e antepassados históricos comuns e cristalizar a angolanidade. Kajibanga (1999/2000/2001: 150) ${ }^{6}$ define a angolanidade como o manifesto colectivo de convivência multi-étnica, multirracial e multicultural de todas as comunidades humanas que habitam no actual território da República de Angola.

93 Para a consecução de uma angolanidade cada vez mais sólida, o poder político deve criar políticas de inclusão das minorias étnicas não-bantu (Vatwa e Khoisan) para que estes passem a ocupar o lugar que lhes é devido ao nível dos órgãos do aparelho de Estado (CARVALHO 2007).

94 Apesar da construção da nação angolana não ter sido a prioridade imediata dos movimentos de libertação nacional, paradoxalmente, a guerra pós-independência em 
Angola (1975-2002) serviu, simultaneamente, de factor de desintegração (étnica e familiar) e de integração nacional. «Foi graças à guerra que boa parte dos angolanos conheceu o seu país e aprendeu a lidar com outros povos e outras culturas» (CARVALHO 2007), sendo ainda a participação nas Forças Armadas um factor para o fortalecimento do sentimento patriótico, o que constitui, como veremos adiante, uma premissa fundamental para a criação de uma identidade nacional.

Este último aspecto, embora pareça fortuito, foi aproveitado pelas partes em conflito para a construção da identidade nacional, consolidando deste modo a terceira corrente enquadrada na teoria de «invenção da nação» de Anthony Smith.

\subsection{Os centros de produção de identidade nacional}

A par de outros canais de consolidação de inclusão e coesão, o poder político angolano serve-se de pelo menos três grandes centros de produção de identidade nacional, nomeadamente, as Forças Armadas, o ensino e a administração pública.

\subsubsection{As Forças Armadas}

97 As forças armadas, como agente socializador e aglutinador, parecem constituir-se no centro de produção de identidade angolana e de promoção da vontade nacional (ALMEIDA 2012) - um dos factores imprescindíveis de poder de um Estado. Primeiro, porque a instituição militar tem na sua missão o ensino patriótico, onde na fase de integração os mancebos aprendem a amar e a defender a Pátria e a respeitar as instituições políticas do Estado (SANTO 2014). Segundo, porque as Forças Armadas congregam elementos de diversas proveniências socioculturais e geográficas do Estado que constituem o seu objecto de defesa. Nesta ordem de ideias, são combatidas todas as tendências de estratificação e/ou exclusão social.

No caso angolano, em função do seu processo histórico ${ }^{7}$ e da diversidade da origem identitária (força política e etnia) dos seus elementos, as Forças Armadas Angolanas (FAA), incluindo a Polícia Nacional, são consideradas o principal centro de produção da identidade nacional (angolanidade) e consequente coesão nacional, por cinco razões:

a. 1. As FAA são constituídas por indivíduos provenientes de todos os grupos étnicos de Angola, reunidos para um único objectivo: a defesa da integridade de uma «Angola una $e$ indivisivel»;

2. As FAA são formadas por elementos provenientes das diferentes forças políticas, anteriormente antagonistas entre si (ELNA - Exército de Libertação Nacional, da FNLA; FAPLA - Forças Armadas Populares de Libertação de Angola, do MPLA; e as FALA Forças Armadas de Libertação de Angola, da UNITA, e ainda, os ex-militares da FLEC);

3. A direcção das FAA é constituída por antigos dirigentes de todas as antigas forças armadas, sendo hoje o chefe Estado-Maior um antigo dirigente das FALA (da UNITA);

4. $O$ carácter de mobilidade das forças armadas fez com que indivíduos de uma determinada região constituam famílias com mulheres de outras etnias, causando aquilo que se pode designar por mestiçagem étnica, o que gera o novo homem angolano despido de qualquer complexo étnico (filhos de pais de etnias diferentes farão filhos com descendências étnicas difusas ou múltiplas). Como resultado, muitos jovens nascidos nos anos 1990 são descendentes de uma multiplicidade de etnias, esbatendo assim nas suas mentes a consciência étnica; 
5. A mobilidade das chefias militares (militares nascidos numa região exerceram funções de comando noutras regiões), à frente de homens, também eles, oriundos de diversos espaços socio-culturais, constitui um factor que dissipa a desconfiança étnica e consolida o sentido de angolanidade no seio das forças armadas angolanas.

99 Os cinco factores contribuem para que Angola possa afastar a possibilidade de uma reivindicação, no seio do poder militar, assente numa base étnica ou regional. Este aspecto reforça a vontade de tornar o território nacional objecto de invasão externa, ao mesmo tempo que favorece a concretização dos objectivos políticos permanentes fora das fronteiras nacionais.

Entretanto, a não inclusão do serviço militar obrigatório no texto constitucional, em vigor desde 2010, constitui um grande erro para a coesão nacional que se pretende. Não sendo obrigatória, a entrada nas FAA está a ser vista hoje como um simples meio de realização pessoal (profissional ou académica) pelos jovens que, não tendo conseguido emprego ou vaga numa universidade, recorrem ao serviço militar para encontrar o que lhes foi negado pelas instituições civis. Como se pode inferir, dificilmente, os filhos da elite ou de outros indivíduos da classe média vão integrar um órgão de Estado, sonegando as funções básicas das forças armadas: a formação patriótica do cidadão e a interacção de indivíduos de vários estratos sociais.

101 Certamente, este é um perigo para o futuro de um Estado moderno que, através do combate da exclusão social no seio militar, tem nas forças armadas um instrumento ao serviço da liderança política do país. Portanto, se o poder militar for apenas de indivíduos provenientes de estratos sociais baixos, o poder político, a longo prazo, não gozará de tranquilidade.

\subsubsection{0 ensino}

A escola em Angola, desde o ciclo primário até ao superior, teve o seu papel socializador mais intenso, até 1991, altura em que vigorou no país o sistema de partido único. Perante um poder político, exercido a meio de um conflito armado, as instituições de ensino passaram a ser o viveiro das bases de apoio à ideologia vigente (comunista) e de promoção do patriotismo e da identidade nacional. As paradas matinais e vespertinas para o entoar do hino nacional, em simultâneo, com o içar e o baixar da bandeira, era uma tradição, então reforçada por círculos de interesse que congregavam adolescentes com vista a serem preparados para futuros soldados, tão logo atingissem a maioridade. o ensino da história e da geografia, aliado ao da língua portuguesa, era fundamental para a formação do homem novo despido de qualquer consciência étnica capaz de provocar divisionismo. «Precisamos de quadros, política e ideologicamente capazes de dirigir e orientar os técnicos na realização dos trabalhos que nos permitam atingir os nossos objectivos de classe». ${ }^{8}$

103 Este excerto de um discurso de José Eduardo dos Santos, Presidente da então República Popular de Angola, caracteriza a filosofia que dominou o ensino em Angola durante os primeiros 16 anos, período em que os alunos de todos os níveis eram inseridos em organizações políticas de base. Esse esforço, além de criar uma sociedade altamente politizada e ávida por defender o seu território de uma invasão externa, constituía também o abafar do sentimento étnico num contexto de guerra-fria em que os pequenos estados eram vítimas das acções dos dois contendores pelo domínio do mundo (EUA e URSS). 
Com o advento do multipartidarismo em 1992, as escolas deixaram de ter o papel de formação patriótica, passando a simples centro de instrução académica. Os estudantes deixaram de exercer actividades extra académicas (dança, competição desportiva, concursos de cultura geral), de contribuir para a organização da escola (conselho de alunos, limpeza) e a escola converteu-se num simples local (monótono) de sistema clássico de ensino e aprendizagem. Contudo, devido à guerra, o êxodo de parte considerável da população do campo para a cidade transformou a escola num centro de convivência de jovens de diversas origens étnicas. As escolas de Luanda, ${ }^{9}$ por esta ser a capital do país e, por isso, o lugar mais seguro, passaram a ser as mais concorridas por jovens de todas as origens. Aliás, até 2009, Luanda era também o principal centro de formação superior em Angola. Esta convivência, que se prolonga geralmente desde o ensino primário até ao local do trabalho, remete para um plano de somenos importância para as diferenças étnicas e eleva a consciência nacional dessa camada que, cada vez mais, vai dominando a máquina tecnocrática da administração pública.

A partir de 2009, com o programa de descentralização universitária que criou sete regiões académicas (sete universidades públicas), com faculdades em todas as províncias do país, dá-se outra dinâmica no processo de formação de consciência nacional. Angola saiu de uma para sete universidades públicas, 10 privadas e 44 institutos e escolas superiores. A existência de centros universitários públicos em sete regiões académicas (abarcando, cada uma delas, duas ou três províncias) conferiu outra mobilidade interna de jovens, de uma província para outra, na busca de um curso de preferência ou de emprego como docente ou assistente administrativo. Aliás, esta mobilidade teve início em 2004 na administração pública, quando jovens acabados de sair da universidade em Luanda, tiveram de se deslocar para outras províncias para obter um emprego, normalmente na administração pública.

\subsubsection{Administração pública}

106 Desde a era colonial, os funcionários da administração pública em Angola sempre foram objecto de rotatividade por todo o território sem se ter em conta qualquer fronteira étnica. Esta filosofia, que visava imprimir dinâmica nas relações interétnicas procurando abafar fortes ligações entre indivíduos letrados de uma mesma região contra a elite do poder dominante, foi herdada pelo poder político do Estado independente, mas desta vez com o fito de transformar cada indivíduo em membro de uma nação supra-étnica.

107 Além do xadrez do poder central em primar por uma representatividade aparentemente justa, sobretudo nos órgãos intermédios do aparelho do Estado, o critério de selecção dos governadores provinciais e dos administradores municipais e comunais colocou de parte o local de nascimento do candidato, tendo em conta apenas a competência político-ideológica e, em alguns poucos casos, a técnica. Esta modalidade estendeu-se para os funcionários técnicos como médicos, enfermeiros, professores e demais funcionários de empresas e da função pública. Esses indivíduos acabaram por fixar permanentemente residência e por formar família nas localidades de trabalho, sem sofrer discriminação étnica, uma vez que isso contrariaria a narrativa política e jurídica do país.

108 Com o advento da paz, e na perspectiva política de serem reduzidas as assimetrias regionais, quer a administração pública, quer as empresas públicas e privadas, 
continuaram nessa direcção, numa altura em que a circulação de pessoas e bens pelo país melhorou substancialmente. Jovens de uma determinada região deslocam-se para outras quer seja para estudar e/ou para obter um emprego.

Casos do género acontecem com a religião. Angola é um estado laico com o predomínio da religião cristã (95\%), distribuída por entre católicos e protestantes, enquanto as restantes são as de predominância bantu ${ }^{10} \mathrm{e}$ a de origem islâmica. Esta última, frequentada maioritariamente por imigrantes do Oeste africano, tem dificuldade em se implantar oficialmente no território. Apesar de ter mesquitas erguidas, desde os anos 1980, em várias localidades (estima-se em 57 locais de cultos com 800 mil membros), até ao momento, o Estado angolano não reconhece esta religião, por supostamente não estar em conformidade com a lei do país. Mas, o que nos parece, esta hesitação do Estado angolano tem mais a ver com razões de ordem cultural do que jurídicas. Pois, para a maioria dos angolanos, os preceitos do Islão são tão estranhos como impostoras, se comparadas com os do cristianismo cujas regras são flexíveis.

Sendo supra-étnica, a religião cristã tem contribuído também para a miscigenação étnica de Angola, na medida em que, além de casamentos entre os seus membros sem ter em conta a origem étnica, bem como a mobilidade das suas elites que trabalham em diversos pontos do país, introduzem nas suas missas e cultos mensagens (canções e pregações) com recurso a línguas dos diversos grupos étnicos, traduzidas para a língua comum: o português. Assim, se por um lado, os crentes sentem-se unidos pela fé, por outro, sentem-se membros de um só país com uma riqueza (diversidade) cultural que pode ser aproveitada para a transmissão da mensagem. É, pois, corrente, ouvirem-se hinos religiosos cantados em diversas línguas nacionais, mas é raro acontecer com as línguas estrangeiras. Tal como acontece com a administração pública, no ensino e em quase todos os sectores, o português é hoje a língua de unidade nacional, pois, além de tornar a mensagem comum para todos, é sobretudo visto como um ganho da história comum.

Miguel Bembe (2013: 467) apresenta cinco vectores para a construção da Nação Angolana:

a. Educar para preservar a identidade nacional e, sob sua inspiração, estimular o desenvolvimento de Angola: só com recursos humanos qualificados e um sistema educativo exigente, eficaz e inclusivo se pode realizar, na prática, um verdadeiro conceito estratégico nacional que traga esperança ao futuro do «Estado-nação» em Angola (já na fase avançada de construção);

b. Fortalecer os sentimentos de pertença nacional (de Cabinda ao Cunene) e os mecanismos de construção de uma cidadania livre e activa. Neste aspecto, o autor defende um discurso da interculturalidade, multiculturalidade e angolanidade que se ajuste a práticas que devem ser dirigidas, num quadro de interdependência, tanto às pessoas que se pretendem integrar, quanto àquelas que devem facilitar essa integração; ${ }^{11}$

c. Formar, permanentemente, para dotar cada cidadão angolano das ferramentas necessárias ao seu progresso individual e colectivo: Em terceiro lugar, as desigualdades na distribuição dos rendimentos, para além de serem sinal de graves desigualdades de oportunidades, especialmente no acesso à educação e valorização profissional de qualidade, devem ser encaradas como uma vulnerabilidade associada aos fenómenos da pobreza, da exclusão social e da criminalidade. As políticas económicas são, assim, um elemento vital para a construção da Nação Angolana;

d. Inovar para conferir especificidade ao país e torná-lo mais competitivo, também pela via da diferenciação. Assim, o desenvolvimento político em Angola deve promover a consolidação 
das novas instituições políticas, sem as quais qualquer tentativa no sentido do desenvolvimento socioeconómico estará bastante fragilizada. «A principal dimensão do desenvolvimento político tem a ver com o processo pelo qual os indivíduos se tornam cada vez mais participativos e integrados na acção política».

112 Não muito diferente de Miguel Bembe, já Paulo de Carvalho (2007) havia apresentado quatro pressupostos para a construção da identidade nacional angolana, a saber:

a. a dignificação do angolano comum, que tem de passar a sentir-se cidadão;

b. o fim de assimetrias na relação do indivíduo com o Estado;

c. uma mais justa distribuição do rendimento nacional; e

d. um maior investimento no acesso ao conhecimento.

\subsection{Fonte estratégica de Angola}

113 Tendo presente que a identidade nacional é um valor que se constrói e se cristaliza ao longo do tempo em consonância com a manutenção da soberania, Angola encontra-se num processo avançado de construção da identidade nacional pelas condições já atrás mencionadas.

114 A consciência patriótica (CARVALHO 2007), que se manifesta em vários momentos da história recente de Angola e abafa as diferenças étnicas entre os angolanos, constitui uma base forte para a afirmação da angolanidade.

115 Por outro lado, sendo o poder político o cérebro para a promoção da coesão e consciência nacional, deverá cada vez mais enaltecer os símbolos e idades de ouro, capazes de elevar o orgulho dos angolanos pelas conquistas comuns. Neste aspecto, as relações entre os diferentes reinos no período pré-colonial, as coligações entre eles contra os invasores externos, bem como o facto de os movimentos nacionalistas nunca terem posto em causa a integridade territorial, mesmo quando os seus líderes divergiam em relação à conquista do poder político no futuro Estado (SÁ 2011), fazem parte das idades de ouro capazes de despertar uma consciência nacional maior. Aliás, este último aspecto tem sido a âncora do discurso do partido no poder que encontra na história e na vitimização do povo angolano o meio para a reprodução do poder.

116 Um estudo realizado recentemente, em Luanda (MENDES et al., 2011), com jovens de diferentes proveniências étnicas, menciona acontecimentos e personalidades que, no seu entender, pela relevância podem constituir a memória colectiva de Angola.

117 Em relação aos acontecimentos, os jovens inquiridos, maioritariamente nascidos nos anos 1990, apontaram a independência de Angola (85,7\%), a assinatura dos acordos de paz em 2002 (70,88\%), a luta de libertação nacional (60,44\%), o massacre da Baixa de Cassange a 4 de Janeiro de 1960 (42,9\%), a morte de Jonas Savimbi a 22 de Fevereiro de 2002 (20,3\%), a tentativa de golpe de Estado a 27 de Maio de 1977 (19,23\%), a abolição da escravatura (17,03\%), a guerra civil (10,9\%), bem como o tráfico de escravos $(10,4 \%)$, são acontecimentos incontornáveis na memória colectiva dos angolanos.

118 Em relação a personalidades, o estudo mencionou os nomes de Agostinho Neto (86,81\%), Jonas Savimbi (78,02\%), Njinga a Mbande (40,11\%), Mandume ya Ndemufayu $(29,67 \%)$, Holden Roberto $(27,47 \%)$, José Eduardo dos Santos $(18,68 \%)$, Nito Alves (13,74\%), Deolinda Rodrigues (13,19\%), Mfulumpinga Nlandu Víctor (9,34\%) e Mário Pinto de Andrade (6,04\%), como figuras cujo percurso contribuiu para a soberania e liberdade dos angolanos. O estudo ressalta, no entanto, dois aspectos em relação a 
figura de Jonas Malheiro Savimbi: a sua morte é considerada um acontecimento mais ou menos positivo (6,67 \%) enquanto o seu impacto como figura histórica é tido por negativo $(0,63 \%)$, devido à controvérsia que envolve o seu percurso. ${ }^{12}$

119 A tentativa de invasão de Angola, no período pós independência, por forças estrangeiras que supostamente tiveram na UNITA o instrumento para este fim, tem custado a este partido político derrotas sucessivas - na guerra serviu para a mobilização da população contra este movimento subversivo, um acto que se repete nos dois últimos pleitos eleitorais realizados em Angola (CAFUSSA 2012).

Contudo, na indicação de acontecimentos e personalidades, de diferentes lugares e forças políticas, verifica-se a ausência de um sentimento étnico na juventude inquirida. Njinga a Mbande e Mandume ya Ndemufayu foram reis em épocas e etnias diferentes, mas por cada um deles ter travado combate contra os portugueses, os inquiridos qualificam-nos como figuras históricas da pretensa nação angolana. Mas o que se constata é o facto de os jovens mencionarem menos eventos e personalidades que integram fases mais remotas da história angolana. A única personalidade anterior ao século XX mencionada foi a rainha Njinga a Mbande e esquecidos os reis dos demais estados étnicos que hoje constitui o Estado angolano, uma das lacunas que devem ser corrigidas pelos agentes de socialização política de Angola.

Outra narrativa em voga em Angola, embora controversa, ${ }^{13}$ diz respeito à forma como se pôs termo ao conflito armado, sem intervenção directa de outros países, depois de terem fracassado todas as negociações mediadas pelas Nações Unidas, Rússia, EUA e Portugal (CAFUSSA 2014). Aliás, este valor constitui hoje o factor de projecção da imagem de Angola e da sua capacidade político-diplomática, quer dentro, quer fora das suas fronteiras. Com a paz, dois elementos se evidenciaram: a capacidade de liderança (valor intangível do conceito estratégica), o potencial económico e militar, bem como uma forte consciência patriótica dos angolanos.

122 Se em África, o factor de projecção da imagem de Angola é o seu Presidente, que pela sua trajectória histórica na liderança do país ${ }^{14}$ é tido como conselheiro para a estabilidade de muitos dos estados em conflito, fora de África é o potencial económico que mais mobiliza a simpatia de vários estados do mundo. Embora careça de uma mensuração científica, é hoje consensual que o angolano fora do seu território é tão orgulhoso das suas conquistas, tanto quanto o é, por exemplo, o americano.

Podemos mesmo afirmar que o processo histórico de Angola fortaleceu a consciência patriótica dos seus filhos, o que constitui uma base fundamental para a cristalização da identidade nacional angolana capaz de apoiar todas as acções do Estado dentro e fora dele. A história tem mostrado que os angolanos «têm a sua identidade fixada com grande nitidez, sendo que os traços mais marcantes dessa identidade vêm de há muitos séculos. Os registos históricos que referem os seus antepassados revelam um povo cujo modo de ser e de agir se pauta pela constância de carácter em todas as situações da sua existência». ${ }^{15}$ Não consentiram aos portugueses a colonização pacífica dos seus territórios, nem uma existência vitoriosa e definitiva no âmbito da então Província e Colónia e, a seu tempo próprio, souberam constituir-se em Estado independente (BEMBE 2013: 179).

Por outro lado, as conquistas (político diplomáticas, económicas e culturais) que Angola vai fazendo no contexto internacional são outros factores que concorrem para o fortalecimento da consciência nacional, procurando os angolanos se evidenciar como 
uma nação forte e unida - ontem considerado destino perdido e hoje como um estado próspero que procura o seu destino no concerto das nações.

\section{Nota conclusiva}

Com o presente texto pretendíamos saber até que ponto a cristalização da identidade nacional angolana pode contribuir para o êxito de uma estratégia nacional a médio ou a longo prazo. Desta questão, derivaram outras inquietações como: existem premissas para uma identidade angolana? Qual é o discurso político-jurídico em relação a esta temática?

A análise do processo histórico angolano bem como da conjuntura interna, conjugados com a teoria de Anthony Smith, leva-nos a concluir que Angola reúne condições para a cristalização de uma identidade nacional que sirva de base para o sucesso de um conceito estratégico nacional.

Como pressuposto básico de uma estratégia nacional, os elementos ontológicos (princípios do princípio) estão reunidos, precisando apenas de serem estimulados pelo poder político. Conforme ficou demonstrado, existe, em Angola, uma memória e um pensamento estratégicos capazes de conduzir toda a acção estratégica no presente.

As máximas, tornadas «palavras de ordem», anunciadas pelo Dr. António Agostinho Neto, primeiro presidente da República - «Angola é e será por vontade própria trincheira firme da revolução em África», ou «Na Namíbia, no Zimbabwe e na África do Sul está a continuação da nossa luta» - estão convertidas hoje em princípios que dinamizam as acções do Estado angolano, visando a eficácia máxima sobretudo no que tange à projecção externa dos objectivos estratégicos de Angola.

Como refere Bembe (2013), trata-se de um povo indómito que sabe ambicionar, sabe sofrer, sabe combater, sendo, em todas as circunstâncias, fiel a si próprio. É simplesmente assim, nas suas virtudes e nos seus defeitos. O seu animus é o seu carácter.

A partir dos pressupostos acima enunciados, Angola dispõe de uma cultura estratégica e uma cultura política, ambas em constante evolução com o recurso a agentes de socialização (forças armadas, ensino, administração pública, comunicação social, partidos políticos e igrejas) que, cada vez mais, procuram exaltar o patriotismo e a unidade nacional.

Embora não haja um conceito estratégico escrito e assumido, percebe-se a existência de um pensamento estratégico assente na construção identitária, da memória colectiva e na capacidade da elite em impôr as modalidades estratégicas a médio e a longo prazo.

Os factores atrás descritos mostram de forma inequívoca que o potencial estratégico de Angola, ao contrário de Estados vizinhos com mais recursos tangíveis (como petróleo e forças armadas), tem nos seus recursos intangíveis (identidade) a maior força para a manutenção da sua soberania e a projecção do seu poder. Esta condição favorável fá-lo um estado próspero num continente onde as diferenças étnicas são o factor de conflito.

Com efeito, ao que parece, o processo da construção da Nação Angolana valoriza a identidade nacional como pressuposto da coesão nacional gerada na base da coesão interna dos povos, pelas mesmas crenças e pelos mesmos mitos, pelos mesmos sacrifícios e pelos mesmos prazeres que, nas mais diversas circunstâncias, inspiraram o 
comportamento das várias comunidades socioculturais que agiu como uma só vontade. A formação da identidade nacional passa necessariamente pela educação patrimonial como veículo que permite as instituições patrimoniais agirem como actores sociais, ajudando as populações a estabelecer ligações entre elas e as suas raízes, o que permite a criação de uma cultura de tolerância, de paz e sobretudo de unidade nacional.

Portanto, se o Estado não pode ser concebido sem população e esta não pode ser pensada sem cultura, inspirada numa origem e uma finalidade comuns, Angola tem o suficiente para ultrapassar antagonismos entre as suas elites, defender-se de qualquer investida externa contra a sua estabilidade e, ao mesmo tempo, impôr-se e influenciar vontades fora dos seus limites geográficos.

\section{BIBLIOGRAFIA}

ALMEIDA P. V., 2012, O poder do pequeno Estado. Lisboa, Instituto Superior de Ciências Sociais e Políticas da Universidade de Lisboa.

ALMOND G. A., POWELL G. B. e MUNDT R. J., 1993, Comparative politics. A theoretical approach. New York, Harper Collins.

ALMOND G. A. e VERBA S., 1963, The civic culture: political attitudes and democracy in five nations. Londres, Sage Publications, Inc. Ver, igualmente, 1963, Princeton, NJ, Princeton University Press.

ALMOND G. A. e VERBA S. (eds.), 1980, The civic culture revisited. Boston, MA, Little Brown.

AMANTE M. F., 2011, «Da persistência dos estudos da identidade nacional», in Identidade nacional entre o discurso e a prática. Porto, Fronteira do Caos, pp. 11-16.

BEAUFRE A., 2004, Introdução à Estratégia. Prefácio do Tenente-General Abel Cabral Couto e do Capitão Liddell Hart. Lisboa Edições Sílabo [«Clássicos do pensamento estratégico»].

BEMBE M. D., 2013, «Os vectores da construção da nação angolana e função do Estado», Mulemba Revista Angolana de Ciências Sociais (Luanda), vol. III, n.ำ 6, Novembro, pp. 167-183.

BEMBE M. D., 2013, A questão de Cabinda: Uma visão estratégica. Evolução da situação e cenários de futuro. Luanda, Edição do Autor.

BERNARDI B., 1974, Introdução aos estudos etno-antropológicos. Tradução de A. C. Mota da Silva. Lisboa, Edições 70 [«Perspectivas do homem»; 6].

CAFUSSA A. C., 2014, O GURN entre a guerra e a paz. Luanda, Edições Mulemba; Ramada, Edições Pedago [«Incubadora das Ciências Sociais e Humanas»].

CAFUSSA A. C., 2012, Tendência de voto do eleitor angolano nas eleições legislativas de 2008. Luanda, Kilombelombe [«Temas \& Debates»; 2].

CARVALHO P. de, 2008, «Estado, etnia, nação e pátria», RAS - Revista Angolana de Sociologia (Luanda), n.. 1, pp. 61-71.

CASTRO C.; SOUZA A. B., 2006, «A defesa militar da Amazônia: entre história e memória», in Celso Castro (org.), Amazônia e defesa nacional. Rio de Janeiro, Fundação Getúlio Vargas, pp. 31-67. 
CONNOR, W., 1994, Ethnonationalism: the quest for understanding. Princeton, New Jersey, Princeton University Press.

COUTO A. C. 1988, Elementos de estratégia. Lisboa, Instituto de Altos Estudos Militares.

FEIJÓ C., 2001, Problemas actuais de Direito Público Angolano. Contributos para a sua compreensão. Cascais, Principia - Publicações universitárias e científicas.

GUERRA J. P., 2002, Savimbi, vida e morte. Lisboa, Bertrand Editora.

FONTOURA L. (coord.), 2013, Segurança e defesa nacional. Um conceito estratégico. Coimbra, Almedina.

JOHNSTON A. I., 1995, «Thinking about strategic culture», International Security, vol. 19, n. 4, pp. 32-64. Ver, igualmente, in P. J. Katzenstein (ed.), The culture of national security. Norms and identity in world politics. New York, Columbia University Press, pp. 216-268.

KAJIBANGA V., 1999/2000/2001, «Crise da racionalidade lusotropicalista e do paradigma da “crioulidade". O caso da antropossociologia de Angola», in África. Revista do Centro de Estudos Africanos da Universidade de São Paulo (São Paulo), n.ำ 22/23 (1), pp. 141-156.

KAJIBANGA V., 2009, «Democracia e dimensão cultural de desenvolvimento: uma reflexão sociológica sobre o caso africano», RAS - Revista Angolana de Sociologia (Luanda), n.o 3, pp. 65-72.

KISSINGER H., 2003, Precisará a América de uma política externa? Uma diplomacia para o século XXI. Tradução de Fernanda O’Brien, Jorge Simões, Lucília Filipe, Maria José Figueiredo. Lisboa, Gradiva.

MARQUES A. A., 2008, «Segurança estatal, cultura estratégica e doutrina militar», disponível em: <http://www.egov.ufsc.br/portal/sites/default/files/anexos/32037-37695-1-PB.pdf>, assessado em 29 de Maio de 2014.

MATOSO J., 2003, A identidade nacional. Lisboa, Gradiva.

MENDES J. et al., 2010, «Memória colectiva e identidade nacional: jovens angolanos face à História de Angola», in Anuário Internacional de Comunicação Lusófona, disponível em: <http:// repositorium.sdum.uminho.pt/handle/1822/16150>, assessado em 21 de Junho de 2014.

MONTESQUIEU [Charles de Secondat], [s.d., 1748], De l'esprit des loix, ou du rapport que les loix doivent avoir avec la constitution de chaque gouvernement, moeurs, climat, religion, commerce, etc.; à quoi l'auteur a ajouté des recherches sur les lois romaines touchant les successions sur les lois françaises et sur les lois féodales. Géneve, Barillot \& Fils, 2 vols.

NETO A., 1980, Ainda o meu sonho. Discursos sobre a Cultura Nacional. Luanda, União dos Escritores Angolanos; Lisboa, Edições 70.

NEUMMAN I. B. e HEIKKA Henrikki, 2005, «Grand strategy, strategic culture, practice: the social roots of nordic practice», Cooperation and Conflict. Journal of The Nordic International Studies Association, vol. 40, n.ำ 1, pp. 5-23.

REDINHA J., 2009, Etnias e culturas de Angola. Coimbra, Associação das Universidades de Língua Portuguesa.

RIBEIRO A. S., 2010, Política de defesa nacional e estratégia militar. Modelo de elaboração. Lisboa, Diário de Bordo.

ROMANA H., 2013, «O conceito de cultura estratégica. Nota sobre a China», in António de Sousa Lara (coord.), A crise e o futuro. Lisboa, Instituto Superior de Ciências Sociais e Políticas da Universidade de Lisboa, pp. 43-50. 
SÁ T. M., 2011, Os Estados Unidos e a descolonização de Angola. Alfragide, Publicações Dom Quixote.

SANTO P. E., 2006, Sociologia política e eleitoral. Lisboa, Instituto Superior de Ciências Sociais e Políticas da Universidade Técnica de Lisboa.

SMITH A. D., 1997, A identidade nacional. Lisboa, Gradiva.

SNYDER J. L., 1984, The ideology of the offensive: military decision making and the disasters of 1914. Ithaca, NY, Cornell University Press.

\section{NOTAS}

1. Como reconhece Henry Kissinger (2003b: 189-191), muitas vezes, as potências coloniais dividiram grupos étnicos ou tribais de forma a complicar o surgimento de uma oposição unificada ao domínio imperial.

2. Com excepção do Uíje, as províncias do Zaire e de Cabinda são as principais produtoras de petróleo em Angola.

3. O Rwanda sempre se opôs ao governo da RDC que, em aliança com Angola, lutou a favor de Joseph Desiré Kabila (enquanto líder de uma rebelião contra o regime de Mobutu Sese Seko), e contra este, e, mais tarde, o seu sucessor (o filho, Joseph Kabila) a favor de outra rebelião. Nesta cruzada, Angola lutou ao lado do governo da RDC, em aliança com África do Sul e o Zimbabwe contra o Rwanda, o Burundi e o Uganda.

4. Apesar de estarem previstas no texto constitucional, desde 1992, as autarquias em Angola nunca foram implementadas por, segundo justifica o aparelho do poder, nunca ter havido condições para o efeito.

5. Os Kwanyama, cujo herói é o soberano Mandume ya Ndemufayu, encontram-se nos dois territórios (Angola e Namíbia), ocupando um espaço significativo entre o Norte e o Sul dos dois países.

6. O sociólogo Víctor Kajibanga, numa comunicação apresentada ao Colóquio O Luso-tropicalismo revisitado, que teve lugar na Sociedade de Geografia de Lisboa, nos dias 11 e 12 de Fevereiro de 1999, e que visava homenagear o sociólogo brasileiro Gilberto Freyre, o pai do luso-tropicalismo, refuta todas as teses que tentam de forma dissimulada impôr a superioridade das minorias que descendem da raça branca nos estados colonizados por Portugal e dentre os quais se inclui Angola (cf. KAJIBANGA 1999/2000/2001: 141-156).

7. As actuais Forças Armadas Angolanas (FAA) são o resultado de uma fusão entre o Exército de Libertação Nacional (ELNA), as Forças Armadas Populares de Libertação de Angola (FAPLA), as Forças Armadas de Libertação de Angola (FALA) e mais tarde por militares da Frente de Libertação do Enclave de Cabinda (FLEC). Como se pode perceber facilmente, os três primeiros foram os braços armados dos movimentos de libertação nacional, respectivamente, a Frente Nacional de Libertação de Angola (FNLA), o Movimento Popular de Libertação de Angola (MPLA) e a União Nacional para a Independência Total de Angola (UNITA) que, apesar de terem um objectivo comum, a independência de Angola, nunca conseguiram um acordo para uma frente única. A história dos três movimentos foi de traição, perseguição e, muitas vezes mesmo, de confronto, ao ponto de o suposto inimigo comum servir de mediador para uma transição pacífica, do colonialismo para a independência a 11 de Novembro de 1975. Essas rivalidades desembocaram na guerra civil que viria a durar cerca de 30 anos, opondo o MPLA à UNITA e àquele à FLEC.

8. Cf. «Discurso» de José Eduardo dos Santos, Presidente da República Popular de Angola, a 17 de Outubro de 1979. 
9. Luanda é a província que hoje alberga $1 / 3$ da população angolana com proveniência de quase todas as comunidades étnicas do país, sendo bastante difícil determinar o grupo mais representativo da população de Angola nessa metrópole. Embora as pessoas se congreguem de acordo com o lugar de origem - há bairros inclusive com designações dos lugares de proveniência dos seus habitantes - a verdade é que a proximidade com pessoas de outras origens torna a diversidade étnica mais dialogante e mais tolerante. Há casamentos e pactos de vária ordem entre famílias e indivíduos.

10. A religião bantu acredita na existência de um Deus, a quem se tem acesso através do culto aos antepassados, que intercedem junto de Nzambi, Kalunga ou Suku - em conformidade com a língua local -, que está no topo das alturas, para que haja chuva, caça, fecundidade, fertilidade, protecção ou punição para os transgressores.

11. Como sugere a Associação para a promoção cultural da criança (APCC), a diversidade deve ser um elemento enriquecedor da sociedade. É um direito inalienável porquanto permite distinguir uma pessoa ou grupo dos demais, evitando qualquer pretensão de uniformização, de massificação, ou mesmo de aniquilação da diferença.

12. Jonas Malheiro Savimbi é, por um lado, acusado de ter colaborado com a potência colonizadora para eliminar os outros movimentos de libertação nacional, nomeadamente o MPLA, por outro, por ter colaborado com os Estados Unidos da América (EUA), a África do Sul e o ex-Zaïre na invasão ao território angolano com o objectivo de comemorar em Luanda a independência de Angola, no dia 11 de Novembro de 1975, e por fim, por violar os acordos de paz para Angola mesmo depois das primeiras eleições multipartidárias (GUERRA 2002).

13. Angola conquistou a paz, em 2002, na sequência da morte do líder da UNITA, Jonas Savimbi, depois de muitos acordos, mediados pelas Nações Unidas e outros países como Estados Unidos, Rússia e Portugal, terem fracassado (CAFUSSA 2014).

14. José Eduardo dos Santos chegou a presidente de Angola aos 37 anos de idade, em 1979, quando o Estado tinha menos de quatro anos, e estava a enfrentar uma guerra civil e uma invasão do território ao Norte e ao Sul por países vizinhos. Estava-se em pleno período da guerra-fria que transformou Angola no estado-tampão. Apesar de a URSS se ter colapsado, nem por isso a força subversiva, apoiada pelos Estados Unidos, conseguiu chegar ao poder. Durante 10 anos (1992-2002), entre acordos fracassados e acções diplomáticas, o poder político se impôs e se reproduziu depois do conflito armado. Um processo de reconciliação foi levado a cabo, com a integração sociopolítica dos dirigentes do antigo movimento subversivo.

15. Breve adaptação das características apontadas ao povo português, no texto elaborado pela comissão constituída para a «Revisão do conceito estratégico de defesa nacional» (de Portugal), coordenada pelo professor Luís Fontoura (FONTOURA 2013: 53-55).

\section{RESUMOS}

O presente estudo está estruturado em duas partes: a primeira, aborda a identidade nacional numa vertente teórico-conceptual, tendo como base a obra de Anthony Smith; tem em conta, igualmente, os demais elementos que ajudam a definir ou determinar o que é um conceito estratégico; na segunda parte, analisa-se a evolução e os pressupostos susceptíveis de tornar a identidade angolana num alicerce sólido para a prossecução dos objectivos nacionais permanentes. 
This study is organized in two different parts: the first one deals with national identity with a theoretical and conceptual approach, based on the work of Anthony Smith. It also takes into account other elements that help to define or determine what is a strategic concept; the second part analyzes the evolution and the assumptions that would make the Angolan identity a solid foundation for the pursuit of permanent national objectives.

\section{ÍNDICE}

Keywords: national identity, strategy, projection of interests, political culture and strategic culture

Palavras-chave: identidade nacional, estratégia, projecção de interesses, cultura política e cultura estratégica

\section{AUTOR}

\section{ALBERTO COLINO CAFUSSA}

albertocafussaa@gmail.com

Assistente do Departamento de Ciência Política (DCP) da Faculdade de Ciências Sociais (FCS) da Universidade Agostinho Neto (UAN) e doutorando em Estudos Estratégicos pelo Instituto Superior de Ciências Sociais e Políticas (ISCSP) da Universidade de Lisboa.

É diplomado em Ciência Política pela Faculdade de Ciências Sociais (FCS) da Universidade Agostinho Neto (UAN) e docente do Departamento de Ciência Política da mesma instituição académica. Actualmente, prepara a sua tese de doutoramento em Estudos Estratégicos, no Instituto Superior de Ciências Sociais e Políticas (ISCSP) da Universidade de Lisboa, Portugal. Entre outros estudos, é autor das obras seguintes: O GURN entre a guerra e a paz (Luanda, Edições Mulemba; Mangualde, Edições Pedago, 2014, 150p.) e A tendência de voto do eleitor angolano nas eleições legislativas de 2008 (Luanda, Kilombelombe [«Temas e debates»; 2], 2012, 208p.). Além de extensa produção jornalística nas áreas de política e economia, publicou os artigos seguintes: «O perfil estratégico do Presidente José Eduardo dos Santos. Uma liderança num mundo em crescente turbulência», Mulemba-Revista Angolana de Ciências Sociais (Luanda), vol. IV, n.o 8, Novembro de 2014, pp. 267-284; «Uma doutrina que resiste ao "fim da história”, o socialismo democrático, 1864-1960, de Jacques Droz», Mulemba-Revista Angolana de Ciências Sociais (Luanda), vol. IV, n. 8, Novembro de 2014, pp. 577-583. «O papel do GURN na pacificação e reconciliação de Angola», Revista Angolana de Sociologia (Luanda), n.. 2, 2010, pp. 53-68; «A nova geografia eleitoral: o caso das eleições de 2008», Mulemba - Revista Angolana de Ciências Sociais (Luanda), vol. II, n. ${ }^{\circ}$, Novembro de 2012, pp. 41-69. Jornalista profissional, passou pelos jornais Angolense (Luanda), Semanário Angolense (Luanda), tendo sido chefe de redacção do jornal Semanário Económico (Luanda). Está, ainda hoje, vinculado ao Jornal de Angola (Luanda). 